\title{
Electrical resistivity tomography (ERT) and sedimentological analysis applied to investigation of Upper Jurassic limestones from the Krzeszowice Graben (Kraków Upland, southern Poland)
}

\author{
Tomasz WOŹNIAK ${ }^{1, *}$, Grzegorz BANIA ${ }^{1}$, Włodzimierz J. MOŚCICKI ${ }^{1}$ and Michał ĆWIKLIK ${ }^{1}$ \\ 1 Faculty of Geology, Geophysics and Environment Protection, AGH University of Science and Technology, al. \\ A. Mickiewicza 30, 30-059 Kraków, Poland
}

Woźniak, T., Bania, G., Mościcki, W.J., Ćwiklik, M., 2018. Electrical resistivity tomography (ERT) and sedimentological analysis applied to investigation of Upper Jurassic limestones from the Krzeszowice Graben (Kraków Upland, southern Poland). Geological Quarterly, 62 (2): 287-302, doi: 10.7306/gq.1403

\begin{abstract}
This paper highlights the application of shallow non-invasive geophysics (electrical resistivity tomography) supported by sedimentological analysis applied to the investigation, description and interpretation of Upper Jurassic limestones exposed in the abandoned quarry near the village of Tomaszowice (Kraków Upland, southern Poland). Within this site, on the northern margin of the Krzeszowice Graben, a facies diversity of Upper Jurassic limestones can be observed. Field exposures were analysed to broadly characterize these Upper Jurassic limestones in terms of facies and microfacies development. Three facies types, including pelitic limestones, bedded limestones and carbonate gravity-flow deposits, composed of numerous microfacies, have been distinguished. ERT study using a dipole-dipole array has been carried out, along 5 parallel $110 \mathrm{~m}$ long profiles and along a perpendicular $110 \mathrm{~m}$ long profile, north of the Tomaszowice Quarry wall. The use of ERT in combination with the geological data allowed characterization and description of the geology at the research site as well as the determination of the lithological composition and internal architecture of the subsurface. Furthermore, the ERT interpretation results indicated the presence of a series of a secondary faults closely linked with the Krzeszowice Graben. The distribution of the gravity-flow deposits reflects the fault zone pattern of the graben and Late Jurassic fault activity.
\end{abstract}

Key words: electrical resistivity tomography (ERT), Upper Jurassic limestones, Oxfordian, Krzeszowice Graben, southern Poland.

\section{INTRODUCTION}

Electrical resistivity tomography (ERT) is an effective, non-invasive geophysical technique, widely applied for the determination of shallow subsurface properties as well as the spatial distribution of these properties embodied in the 2D and 3D images. Because of this, ERT has been successfully integrated, in particular, in sedimentological studies in geology (see e.g., Hirsh et al., 2008; Šilhán and Pánek, 2010; Pellicer and Gibson, 2011; Ćwiklik, 2013; Mościcki et al., 2014; Kozłowska et al., 2016).

The Kraków Upland, and in particular the tectonic margins of the Krzeszowice Graben (Fig. 1) are perfect places at which Upper Jurassic limestones of diverse facies can easily be observed (see e.g., Dżułyński, 1952; Matyszkiewicz, 1997). Along the graben margins, these Upper Jurassic limestones are commonly exposed, and show considerable sedimentological, lithological and tectonic variability across short distances (see

\footnotetext{
* Corresponding author, e-mail: twozniak@geol.agh.edu.pl
}

Received: June 12, 2017; accepted: December 20, 2017; first published online: April 3, 2018 e.g., Matyszkiewicz, 1996; Matyszkiewicz and Krajewski, 1996; Krajewski, 2000) while their lateral extents, restricted by the size of exposures, remain poorly constrained.

We focus here on the combination of ERT with geological analysis to provide complementary data on these Upper Jurassic limestones. While such geophysical surveys have in general become more widely applied, the use of ERT in this study is its first application to the Krzeszowice Graben, though ERT has been applied north of the Kraków Upland (in the area of Bydlin) by Barski and Mieszkowski (2014).

This case study was carried out in a small abandoned quarry located near the village of Tomaszowice, near Kraków, in the southern part of the Kraków Upland (Figs. 1 and 2). Although the Upper Jurassic limestone facies from this quarry, have already been briefly described by Ziółkowski (2007b), who recognized three facies in these Upper Jurassic limestones as well as erosive contacts between some of them, their development has until now not been studied in detail.

Our objective, in this paper, has focused on: (1) highlighting the potential of ERT for investigation and reconstruction of these Upper Jurassic rocks, (2) identifying and describing the carbonate facies encountered in the study site, (3) defining the spatial distribution together with boundaries between each facies by correlating the obtained ERT results with lithological characteristics as well as (4) providing information about the possible presence of tectonic structures in the research area. 


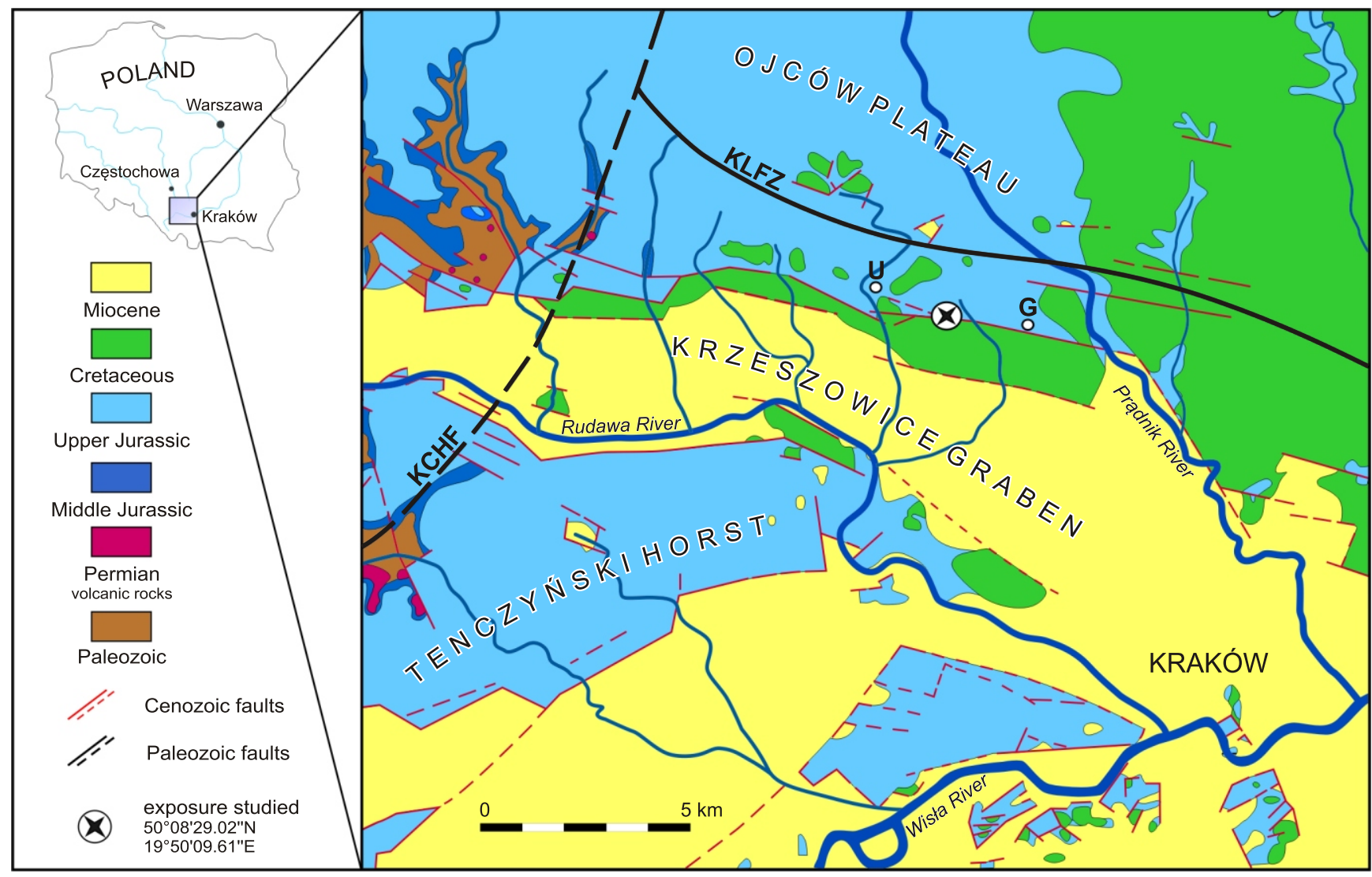

Fig. 1. Position of the Upper Jurassic limestones analysed in the area of Tomaszowice (asterisk) superimposed on a geological map of the southern part of Kraków Upland (after Gradziński, 2009, simplified and modified)

Position of the KLFZ (Kraków-Lubliniec Fault Zone) and KCHF (Krzeszowice-Charsznica Fault) disturbing the Paleozoic basement after Habryn et al. (2014); white dots with annotations indicate Upper Jurassic outcrops mentioned in the text: U - Ujazd; G - Giebułtów

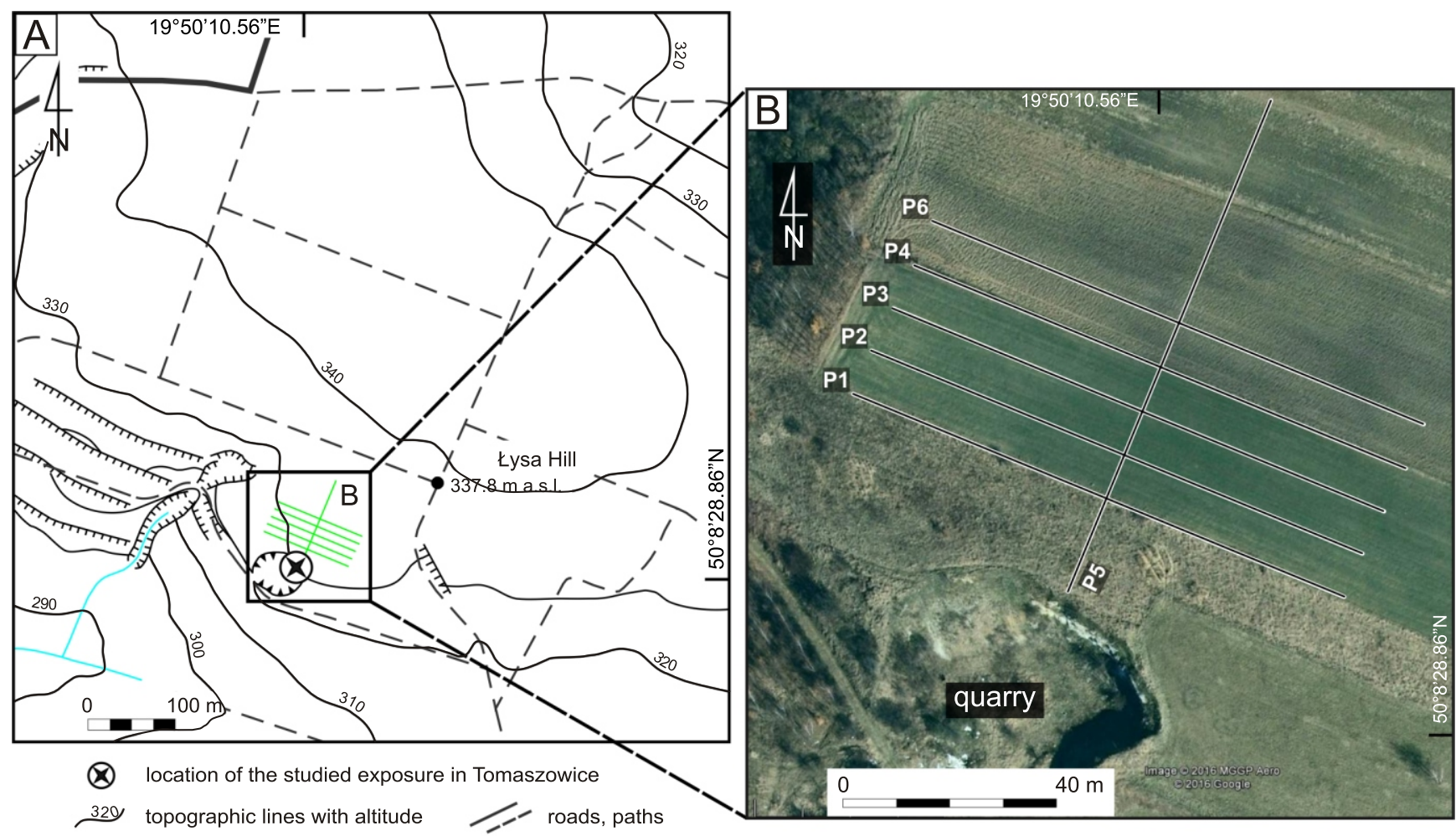

IلII morphological edges stream

Fig. 2A - location map of the abandoned quarry at Tomaszowice with the marked positions of the ERT survey lines (green lines), the part in the rectangle is magnified in Figure 2B; B - detailed location of the ERT survey lines superimposed on the digital orthophotomap of the area investigated (source of orthophotomap: Google Earth web site) 


\section{GEOLOGICAL SETTING}

The Krzeszowice Graben is one of the largest of all numerous grabens that occur within the regional tectonic unit of the Silesian-Kraków Homocline, and is the most easily apparent structure among the modern landforms of the Kraków Upland (Fig. 1).

The homocline is built of Mesozoic sedimentary rocks (Triassic, Jurassic and Cretaceous) that dip gently, at a low angle, towards the NE, and rest unconformably on the pre-Mesozoic basement of the homocline, which consists of folded Precambrian and Paleozoic rocks. The homocline basement is cut by the Kraków-Lubliniec Fault Zone (KFLZ) and the Krzeszowice-Charsznica Fault (KCHF; Buła et al., 2002; Habryn et al., 2014; Narkiewicz and Petecki, 2017). The KLFZ, which divides the homocline basement into the Upper Silesian Block and the Małopolska Block (Żaba, 1995, 1999) has been active since the earliest Paleozoic (Morawska, 1997; Żaba 1999). Moreover, this tectonic zone, especially along the boundary of the Małopolska Block, includes many Paleozoic intrusions (Buła et al., 1997; Żaba, 1999).

The unique readability of the Krzeszowice Graben within the Silesian-Kraków Homocline has been conditioned by the differences in erosion between the Miocene strata filling the graben and the rocks forming the graben margins (mainly Upper Jurassic limestones). A second factor was the Paleogene-Neogene movements which enabled erosion of the Miocene infill.

The southern margin of the Krzeszowice Graben was defined by Dżułyński (1953) as the Tenczyński Horst while the northern margin has been referred to as the Ojców Plateau (Bogacz, 1964, 1967; Fig. 1); they reflect the narrow zones of this complicated faulted structure. Although it is generally recognized that Cenozoic tectonics (linked with the overthrusting Carpathian nappes) was responsible for generating the faults that framed the tectonic structure of the Krzeszowice Graben (Dżułyński, 1953; Gradziński, 1972), this process may have been initiated in the Late Jurassic or even earlier (Matyszkiewicz, 1996; Matyszkiewicz et al., 2007; Nawrocki et al., 2008; Habryn et al., 2014; Matyja and Ziółkowski, 2014).

The Upper Jurassic strata of the present-day Kraków Upland, the thickness of which reaches $\sim 250 \mathrm{~m}$ (Matyszkiewicz et al., 2015b), are diverse, consisting of massive and bedded facies as well as reworked sediments that are related to gravity flow processes (Fig. 3).

The Upper Jurassic bedded facies (also called a "normal facies"; vide Gwinner, 1976) are represented by thin-bedded marl-limestone alternations, bedded pelitic limestones and bedded limestones with early diagenetic cherts, and bedded limestone-marl strata known from well logs (Burzewski, 1969). It is commonly accepted that the sedimentary environment of the bedded facies was placed in the inner-depressions (intrabiohermal depressions) between elevated, by up to $100 \mathrm{~m}$ (cf. Matyszkiewicz, 1999), parts of the carbonate buildups and on their slopes (cf. Dżułyński, 1952).

The Upper Jurassic massive facies, defined by Dżułyński (1952) as unbedded limestones without cherts, consist of preserved fragments of various types of sponge-microbial, microbial-sponge as well as microbial carbonate buildups (Matyszkiewicz et al., 2012). Locally, within these buildups, rare accumulations of brachiopods infill neptunian dykes (Matyszkiewicz et al., 2016).
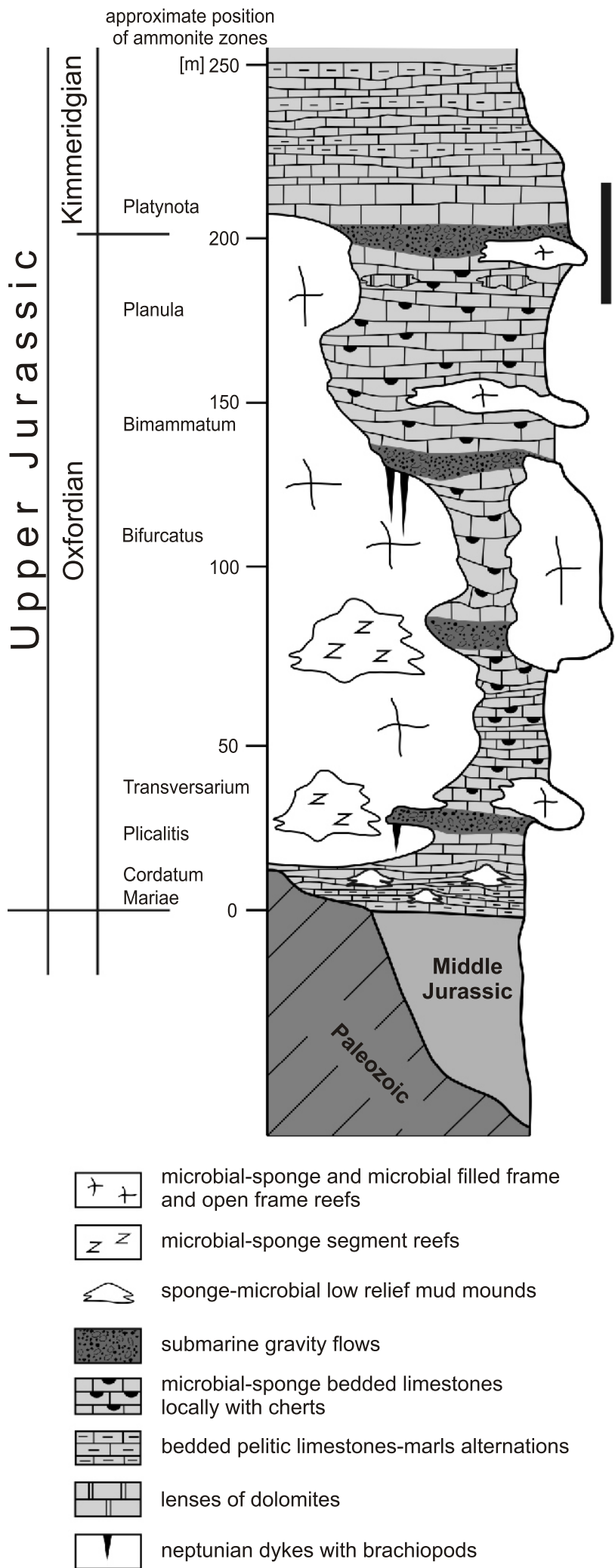

Fig. 3. Lithostratigraphic section of Upper Jurassic strata in the southern part of the Kraków Upland (after Matyszkiewicz et al., 2016, modified) with probable stratigraphic position (black line) of Upper Jurassic limestones exposed at the site 
Almost the entire Upper Jurassic succession of the Kraków Upland hosts a wide variety of gravity flow sediments. These sediments reveal a high lithological variety, among which are grain flow and debris flow deposits as well as calciturbidites and tempestites (Bukowy, 1960; Głazek and Wierzbowski, 1972; Hoffman and Matyszkiewicz, 1989; Matyszkiewicz, 1993, 1996, 1997; Koszarski, 1995; Matyszkiewicz and Krajewski, 1996; Matyszkiewicz et al., 2007, 2015b; Matyszkiewicz and Olszewska, 2007). These deposits are widely encountered along the boundaries that define the graben margins, especially lengthwise along the narrow northern zone of the Krzeszowice Graben (Matyszkiewicz, 1996; Ziółkowski, 2007a, b; Matyszkiewicz et al., 2012).

Reworked sediments are the most accentuated at the boundary between the Upper Oxfordian and Lower Kimmeridgian (Matyszkiewicz, 1996). In addition, gravity flow deposits were identified in the part of the profile that belongs to the Middle and Lower Oxfordian (Koszarski, 1995). The factors that affected the formation, development and size of the gravity flow deposits were closely related to: (1) the differential sea-bottom relief between the carbonate buildups and the basins between them; (2) a temporary deterioration of conditions controlling the growth of the carbonate buildups (initial drowning, cf. Bice and Stewart, 1990); (3) the synsedimentary tectonics associated with the KLFZ activity as well as (4) sea level fluctuations (see e.g., Matyszkiewicz, 1996, 1997, 1999; Matyszkiewicz et al., 2007, 2015b, 2016).

Our geological studies were carried out in a small abandoned quarry $\left(50^{\circ} 08^{\prime} 29.13^{\prime \prime} \mathrm{N}\right.$; $\left.19^{\circ} 50^{\prime} 09.79^{\prime \prime} \mathrm{E}\right)$ located in the complex area that separates the Ojców Plateau from the vast, east-west trending Krzeszowice Graben, near the village of Tomaszowice, in the southern part of the Upland (Figs. 1 and 2). The precise stratigraphic level of the succession analysed, generally ascribed as belonging to the Oxfordian, remains unknown due to a lack of zonally significant ammonite faunas. Precise stratigraphic levels have been defined in Upper Jurassic limestones exposed near Ujazd (the boundary between the Oxfordian and the Lower Kimmeridgian), 2 km west of the exposure studied and at Giebultów (Lower Kimmeridgian) $\sim 4 \mathrm{~km}$ east of the succession studied, respectively (Ziółkowski, 2007a, b).

\section{METHODS}

The exposure was described and sampled prior to the geophysical survey. Sedimentological analysis focused on facies and microfacies characterization of the exposed limestones. Samples were collected from the quarry wall, spanning the entire thickness of the Upper Jurassic limestones. Detailed microfacies analyses was carried out on 18 thin sections and 12 polished slabs. All limestone samples were subsequently clas- sified using Dunham (1962) scheme with its later modifications by Embry and Klovan (1972).

ERT acquisition was performed using a SuperSting $R 8$ resistivity meter, connected to a linear array of 56 electrodes simultaneously (setup) with basic electrode spacing $\Delta x=2 \mathrm{~m}$. In this paper, the dipole-dipole array type was used, as it is highly sensitive to horizontal changes in resistivity and is widely used in the investigation of near-surface resistivity variations (cf. Szalai and Szarka, 2000; Dahlin and Zhou, 2004). Lengths of current and potential dipoles $a=1,2,3,4,5,6 \Delta x$ and separation factors (distances between current and potential dipoles), $n=1,2,3,4,5,6$ a have been used. In total, 5 parallel (P1-P4, P6) $110 \mathrm{~m}$ long survey lines, separated by each other by $10 \mathrm{~m}$ as well as one survey line perpendicular to the quarry wall $110 \mathrm{~m}$ long (P5) were acquired. ERT survey was made in two stages. During the first phase of ERT measurement (June, 09.2016) two survey lines (P1-P2) were established, whereas the remaining survey lines (P3-P6) were conducted during the second stage (September, 09.2016). In order to avoid quarry wall effects on the measurement result, the first survey line P1 was placed $\sim 21 \mathrm{~m}$ from the quarry edges. The perpendicular survey line P5, which starts at the edge of the quarry, cuts the $\mathrm{P} 1$ line at $56 \mathrm{~m}$ length. Locations and measurement parameters of each survey line are shown in Figure 2 and Table 1.

Geodetic measurements, with the use of the Jogger 20 leveler of Leica Geosystems, were conducted simultaneously with the geophysical surveys for the purpose of establishing electrode elevations along each profile. Such measurements are necessary to determine the terrain morphology which significantly influences the data inversion process (Bania, 2011).

The obtained apparent resistivity datasets, along the designated survey lines, were inverted using Res2Dinv of Geotomo Software (Loke, 2010). The inversion process based on the L1-norm (robust, blocky) and L2-norm (smooth) inversion method was tested. In this paper, we provide inverted resistivity sections only for the robust inversion method, which tends to produce models with a much sharper and straighter boundary between different regions with different resistivity values (Loke et al., 2003). All inversion data provide root mean square error (RMS) of between 0.99 and $2.50 \%$ (with a mean value of $1.60 \%$ ) which reflects high data quality.

In order to analyse the resistivity sections in terms of the occurrence of sharp "structural" boundaries, analyses of the vertical and horizontal gradients of the interpreted resistivity distribution was performed. General interpretation of the obtained ERT results was primarily based on correlation with the exposed Upper Jurassic lithologies, for which different facies were assigned. To show a general picture of the geological structure, contour maps of first and second class top surfaces have been created. The depths for each contour map were determined over a height point ' 0 ', which was adopted from the ERT data.

Main characteristics of the ERT survey lines

\begin{tabular}{|c|c|c|c|c|c|c|c|c|}
\hline \multirow[b]{2}{*}{ No. } & \multirow{2}{*}{$\begin{array}{c}\text { ERT } \\
\text { survey lines }\end{array}$} & \multicolumn{7}{|c|}{ Parameters } \\
\hline & & $\begin{array}{c}\text { Profile } \\
\text { orientation }\end{array}$ & $\begin{array}{c}\text { Profile } \\
\text { length }[\mathrm{m}]\end{array}$ & $\begin{array}{c}\text { Electrodes } \\
\text { used }\end{array}$ & $\begin{array}{l}\text { Electrodesse } \\
\text { paration [m] }\end{array}$ & $\begin{array}{c}\text { Electrodes } \\
\text { configurations (array) }\end{array}$ & $\begin{array}{l}\text { Data points } \\
\text { number }\end{array}$ & RMS error [\%] \\
\hline 1 & $\mathrm{P} 1$ & \multirow{4}{*}{ NW-SE } & \multirow{6}{*}{110} & \multirow{6}{*}{56} & \multirow{6}{*}{$\begin{array}{ll}1 \\
\end{array}$} & \multirow{6}{*}{$\begin{array}{c}\text { dipole-dipole } \\
\begin{array}{c}a=1-6 \\
n=1-6\end{array}\end{array}$} & \multirow{6}{*}{$\sim 1323$} & 1.0 \\
\hline 2 & $\mathrm{P} 2$ & & & & & & & 1.2 \\
\hline 3 & P3 & & & & & & & 2.5 \\
\hline 4 & P4 & & & & & & & 1.7 \\
\hline 5 & P5 & NE-SW & & & & & & 2.2 \\
\hline 6 & P6 & NW-SE & & & & & & 0.99 \\
\hline
\end{tabular}




\section{RESULTS}

MACROSCOPIC OBSERVATIONS AND MICROFACIES DEVELOPMENT OF LIMESTONES EXPOSED IN THE TOMASZOWICE QUARRY

In the W-E trending wall of the abandoned Tomaszowice Quarry, the facies relationships in the limestones can be observed (Fig. 4).

The lower part of the Upper Jurassic succession begins with yellowish pelitic limestones (F1; Fig. 4). This part of the succession is only exposed in the lowermost eastern bottom part of the quarry, and a single sample was collected for microfacies study. Thin sections show fine bioclastic wackestones with abundant sponge spicules, fragments of thin-shelled bivalves and radiolarians (Fig. 5A) while single echinoderm plates and foraminifers are also present. Pressure dissolution features represented by horizontal (locally subhorizontal) and/or subordinately vertical stylolites lined with Fe-oxides are very common. Moreover, the wackestones are intensely bioturbated, though the diversity of the trace-fossil associations throughout this microfacies is very low. Generally, two types of burrows, Chondrites isp. and ?Planolites isp., were observed.

Upwards, the pelitic limestones are replaced by $\sim 3$ m thick succession consisting of bedded facies varying in thickness, which are represented by limestones with cherts and locally with marly intercalations (F2, Fig. 4). Weathered limestone surfaces show numerous calcified siliceous sponges up to several tens of centimetres across. The chert nodules, locally densely fractured, represented by elliptical bodies up to $13 \mathrm{~cm}$ across and elongated horizontally bodies up to $25 \mathrm{~cm}$ long, are distributed mainly parallel to the bedding planes. Towards the central part of the wall, the bedding is less distinct and obscured by chaotically distributed cherts. Microscopically, the bedded limestones are developed as bioclastic wackestones-packstones as well as boundstones (Fig. 5B). In microscopic view, the dominant wackestone-packstone components are enigmatic microencrusting fossils such as Crescentiella morronensis (former Tubiphytes sp., cf. Senowbari-Daryan et al., 2008) accompanied by numerous bioclasts dominated by bivalves shells, a variety of siliceous sponge spicules, Terebella lapilloides, plates of echinoderms, bryozoans, serpulid tubes, calcareous sponges as well as foraminifers and holuthurian sclerities. Some of the bioclasts have evident thin micritic envelopes. Among the main recognisable detrital components, tuberoids, oncoids, intraclasts and subordinate small ooids are also evident. Locally in the wackestones, small, irregular borings are also apparent. The prominent components of the boundstones are microbialites together with the calcified siliceous sponges which form so-called "unitary sedimentary sequences" (cf. Gaillard, 1983; Matyszkiewicz, 1989; Olóriz et al., 2003; Reolid et al., 2005). The sponges provided suitable substrates for encrusting or attaching epifauna on their lower surfaces (mainly serpulids and bryozoans), whereas the opposite, upper sponge-surfaces were overgrown by diverse microbialites. The spectrum of microbialites is very wide and includes stromatolite and thrombolite structures. Sponges bearing numerous borings as well as some inhabitants related to Bullopora sp. within the skeletal sponge meshwork could be observed. Furthermore, numerous Crescentiella morronensis showing up to $0.3 \mathrm{~mm}$ thick walls, agglutinated, oval annelid worm tubes that correspond to Terebella lapilloides and individual benthic foraminifers are also frequent. Stylolites, which are commonly accompanied by brownish Fe-oxides within the boundstone microfacies, are very common.
The uppermost part of the Upper Jurassic succession is represented by massive assemblages of limestone clasts and chaotically distributed cherts, referred to gravity-flow deposits (F3, Fig. 4A-B). The limestone clasts are poorly sorted and their dimensions varied from several $\mathrm{cm}$ up to several tens of $\mathrm{cm}$. Clast packing within this unit is variable and shows clast-supported and to a lesser extent matrix-supported fabric (Fig. 4C). Moreover, the limestone clasts are generally distributed fairly randomly and their orientation is chaotic. Locally, subtle inverse grading could be observed (Fig. 4C). The microfacies development of the limestone clasts within the gravity-flow structure are notably diverse, both vertically and laterally (Fig. 5C-F). The clasts are developed as: (1) detrital sediments, mostly as packstones, grainstones and wackestones with very abundant Crescentiella morronensis; (2) microbial-Crescentiella boundstones; (3) bioclastic packstoneswackestones as well as (4) microbial-sponge boundstones with Crescentiella.

The boundary that separates the gravity-flow deposits from the underlying bedded facies extends along sharp irregular discontinuity surfaces. Especially in the extreme western part of the quarry wall, this surface is undulating and forms a presumably $\mathrm{N}-\mathrm{S}$ or NE-SW erosional trending channel (Fig. 4B). Locally, this boundary is also emphasized by the occurrence of a thick layer, up to $15 \mathrm{~cm}$ thick, of brownish-greenish marl (Fig. 4D). The marl contains small angular limestone clasts up to several $\mathrm{cm}$ across and abundant microfossils among which foraminifers (Ammobaculities sp., Dentalina sp., Paalzowella turbinella, Rumanolina elevata, $R$. seiboldi, Spirillina elongata, Sp. infima, Sp. tenuissima), radiolarians (Spumelaria), numerous spicules and skeleton fragments of siliceous sponges, echinoids, holothurian sclerites, coccoliths as well as otoliths were identified.

The Upper Jurassic succession exposed in the quarry wall hosts discontinuities of various origins. Notably, in the western part of the quarry wall, the limestones are cut by a $\sim 2 \mathrm{~m}$ long vertical joint, widening up to $16 \mathrm{~cm}$ across in its bottom part (Fig. 6A). This joint is filled with several $\mathrm{cm}$ thick accumulations of epigenetic siliceous precipitates as well as with a brown clayey karstic residuum. Other indistinct discontinuities could also be observed within the gravity-flow structure. These wavy, irregular and/or nearly-flat surfaces divided the entire deposit into several units (Fig. 4B). In the eastern part of the quarry wall, the limestone facies are dissected by a presumably ENE-WSW striking fault, dipping at a high angle (Fig. 6B), accompanied by breccias.

\section{GEOELECTRICAL SURVEY RESULTS}

The ERT inversion results, which are given in Figure 7, show that the range of interpreted resistivity values is considerable, from 10 to $>1000 \Omega \mathrm{m}$. At the same time the following patterns are apparent in the interpreted sections:

(1) The near-surface zone is dominated by a low-resistivity layer, of variable thickness, whose resistivity values are $<20 \Omega \mathrm{m}$. In the central part of the P1 section the thickness of this layer is $\sim 3-5 \mathrm{~m}$ (ca. $x=24-86 \mathrm{~m}$ ) while at the ends of the cross-section it is significantly smaller $(\sim 1 \mathrm{~m})$. In the further sections a considerable increase in thickness of the low resistivity layer can be observed. In the P6 section their thickness is $>10 \mathrm{~m}$ (ca. $x=56 \mathrm{~m}$; Fig. 7).

(2) The layer underlying the low resistivity layer is characterized by much higher resistivity values (several hundred $\Omega \mathrm{m}$ or more). The significant variability of this layer 

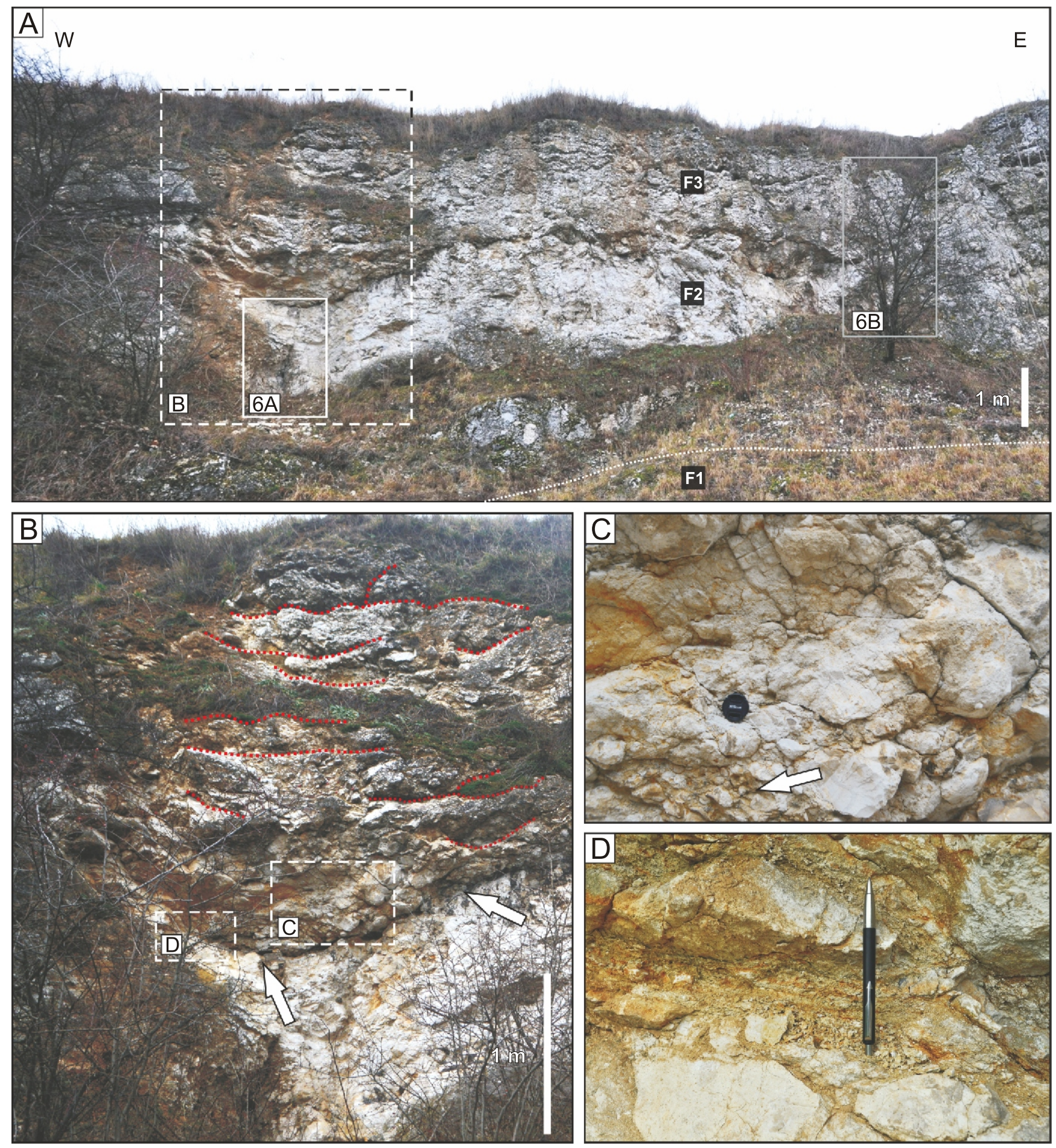

Fig. 4. Field pictures

A - general view of the exposure encountered in the abandoned Tomaszowice Quarry: three diverse Upper Jurassic facies among which pelitic limestones (F1), bedded limestones (F2) and carbonate gravity-flow deposits (F3) can be observed (cf. Ziółkowski, 2007b). Areas in the dashed rectangle magnified in Figure 4B and in grey rectangles magnified in Figure 6A, B; B - Detail of the sharp, erosive contact with channel structure (arrows) between Upper Jurassic carbonate gravity-flow and bedded limestones (respectively F3 and F2, Fig. 4A). Upper part: internal layering of individual gravity-flow units (red dotted lines). Areas in rectangles magnified in Figure 4C, D; C - densely packed clast-supported carbonate gravity-flow deposits composed of angular to subrounded limestone clasts with only minor fine-grained matrix. Sutured edges of the limestone clasts are commonly stylolitized. Lower left part: subtle inverse grading in the basal part (arrow; Nikon lens cap for scale); D - a layer of marls with platy, mm-scale fissility dipping at a low angle towards the $\mathrm{N}$ or $\mathrm{NE}$, occurs locally within the erosional channel at the top of the bedded limestones (pen for scale) 

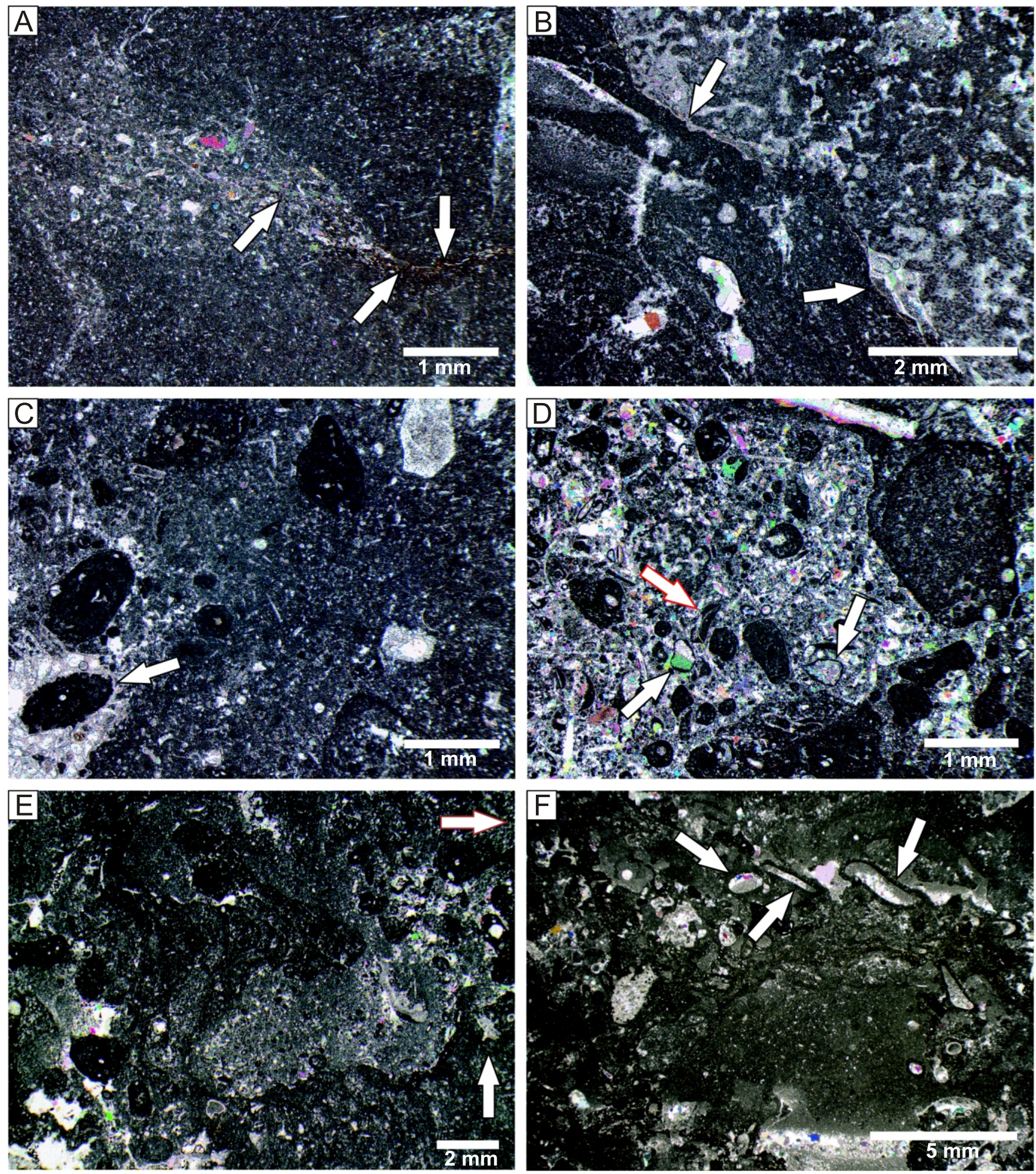

Fig. 5. Thin-section photomicrographs of Upper Jurassic limestones from the Tomaszowice Quarry

A - burrowed fine-bioclastic wackestones; centre and right: an distinct burrow enriched with abundant echinoderm detritus with common echinoid spines, the whole burrow structure is cross-cut by subhorizontal, low-angle stylolites lined by iron-bearing oxides (white arrows); B microbial-sponge boundstones with Crescentiella, the outer surfaces of calcified siliceous sponges (upper right and right) are bordered by stylolites (white arrows); C - wackestones with common Crescentiella; lower left: Crescentiella surrounded by bryozoans in which the cyanobacterian crust continues around and penetrates partly into the bryozoan cavities (white arrow); D - packstones, with common Crescentiella, oncoids with bioclasts in the nuclei (red arrow), tuberoids, intraclasts and numerous unidentified crushed bioclasts, some of the bioclasts tend to have a micritic envelopes (cortoids; white arrows); $\mathbf{E}$ - microbial-Crescentiella boundstones, the present position of the bottom-top direction is indicated by the white arrow, while the red arrow indicates the original top; $\mathbf{F}$ - microbial-sponge boundstones with Crescentiella, upper part: reoriented geopetal infills consisting of fine-grained internal sediments and blocky cement (white arrows) above the cavity 

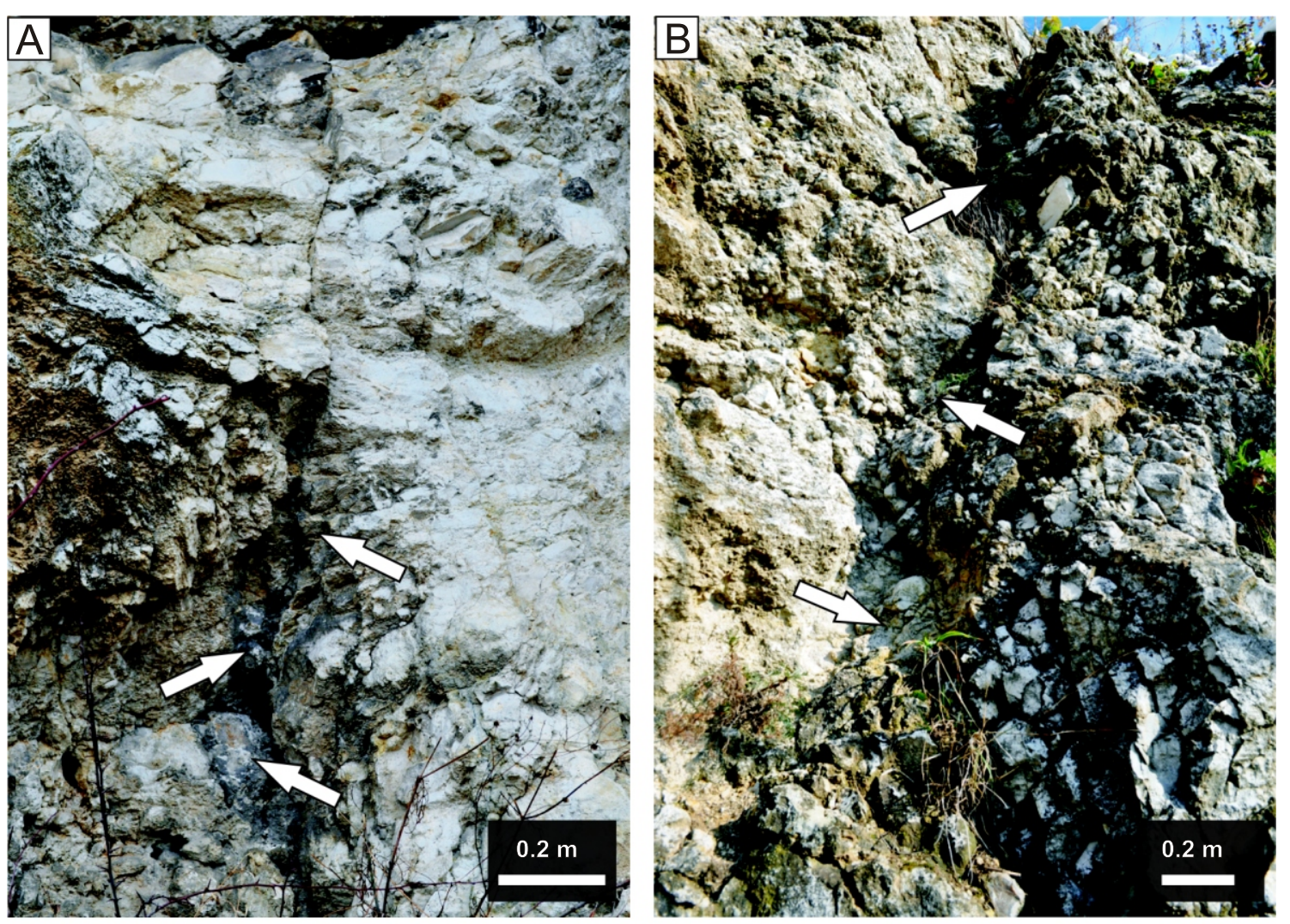

Fig. 6. Discontinuity surfaces

A - high-angle fractures, cutting through Upper Jurassic bedded limestones (F2, Fig. 4), filled with the epigenetic precipitates (white arrows) and karstic clayey residuum; B - weathered fault breccia: contact between breccia and surrounding Upper Jurassic limestones extends along the steep surface (white arrows); see locations in Figure 4A

is apparent between sections. In section $\mathrm{P} 1$, this layer occurs shallowest at the NW and SE ends of the electrical sections, while a clear depression can be seen on its course (including at 30-70 m; Fig. 7). Clear differences in the resistivity values within this zone, both in the horizontal and vertical directions, are present. The depression noted is also clearly visible within the next, $\mathrm{P} 2 \mathrm{sec}-$

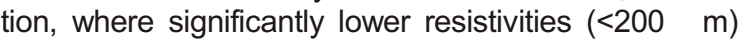
are apparent in the SE part of the section. In the next sections, P3 and P4, the high resistivity layer has consistently much higher resistivity values than in previous sections, and the top surface of this layer occurs at greater depths. A clear change appears between the sections P4 and P6. The top surface of the high resistivity layer in section P6 is weakly marked and is located at least $20 \mathrm{~m}$ below ground level.

(3) The ERT P5 section, perpendicular to the parallel survey lines grid, shows a stepwise structure of the high resistivity layer (Fig. 7).

\section{DISCUSSION}

INTEGRATION OF SHALLOW GEOPHYSICAL SURVEY WITH GEOLOGICAL DATA

Comprehensive geophysical-geological interpretation. The value determined in the DC resistivity measurements is defined as the apparent resistivity, which is a function of many pa- rameters, such as true resistivity distribution, type of electrode array, and its size and position in relation to the geological structures (Mościcki and Antoniuk, 1999). In order to obtain the information about the true resistivity distribution, the apparent resistivity measured in the field undergoes a quantitative geophysical interpretation (inversion), in which ambiguity is an inherent feature (Loke, 2011). An additional complication is that the obtained 2D model resistivity section assumes that the measurements were carried out on a profile perpendicular to the axis of the geological structure. This is rarely met because the geological structure is unknown. It causes the "error" in the interpretation, resulting from the $2 \mathrm{D}$ approximation of the real, spatially diverse geological structure (Loke and Barker, 1996). Therefore, the resistivity section obtained from inversion should be treated as an approximation of the true resistivity distribution.

The integration of geophysical and sedimentological data has led us to the reconstruction of the shallow facies architecture of the Upper Jurassic limestones in the area of Tomaszowice. In order to facilitate the resistivity distribution analysis that was obtained from the inversion process, three resistivity classes were distinguished (Fig. 8). Taking into account all the data obtained, the appropriate lithologically diverse facies type (Fig. 9) has been assigned to a particular resistivity class.

The first resistivity class, which represents the range of resistivity $>300 \Omega \mathrm{m}$ (cf. Fig. 8), most likely corresponds to solid limestones and presumably represents two distinct facies types. One of these, in cross-sections P1 and P2 (Fig. 9), can be interpreted as a continuation of the carbonate gravity-flow 

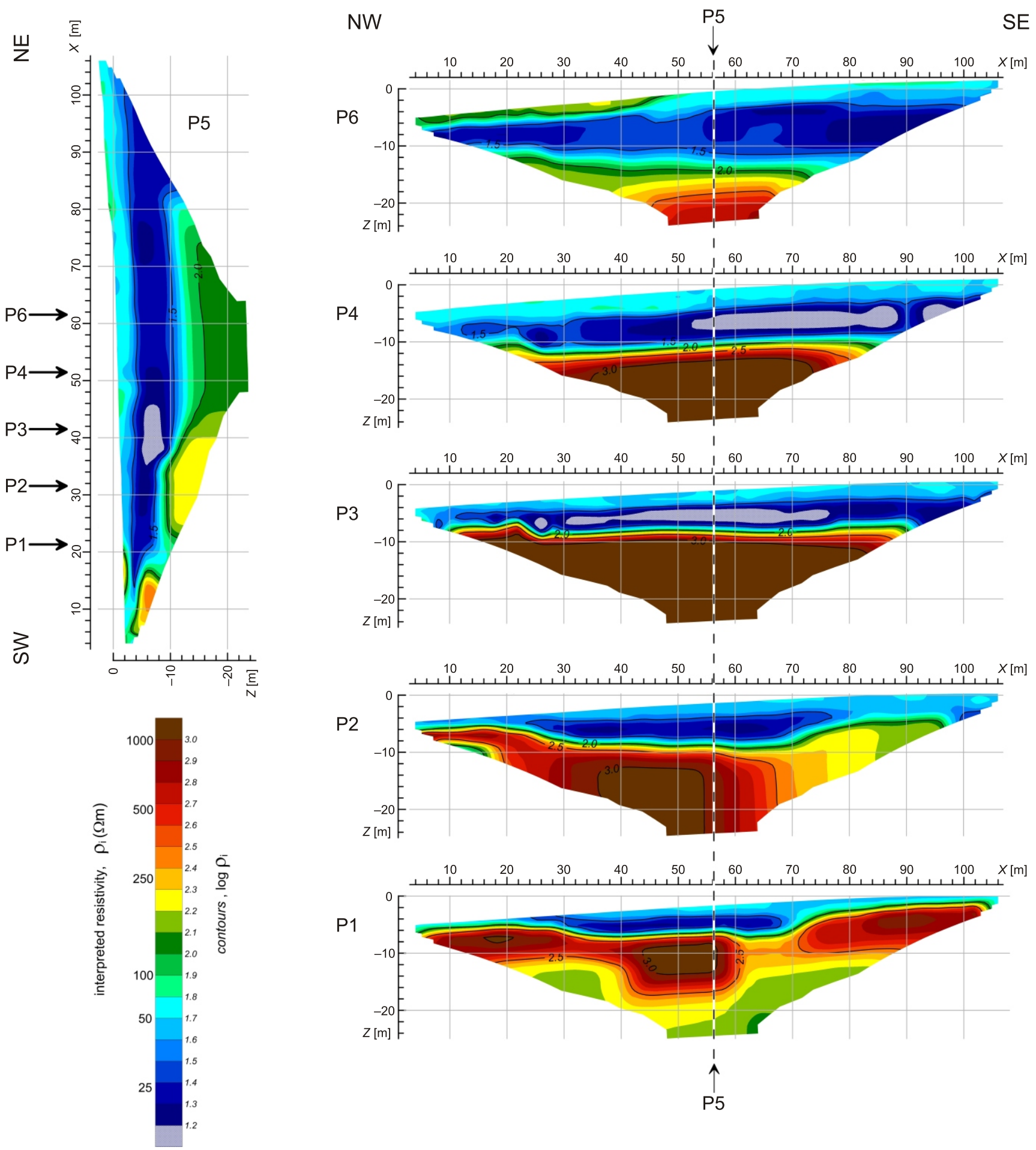

Fig. 7. ERT field data inversion results

The position of each survey line is indicated on Figure 2 

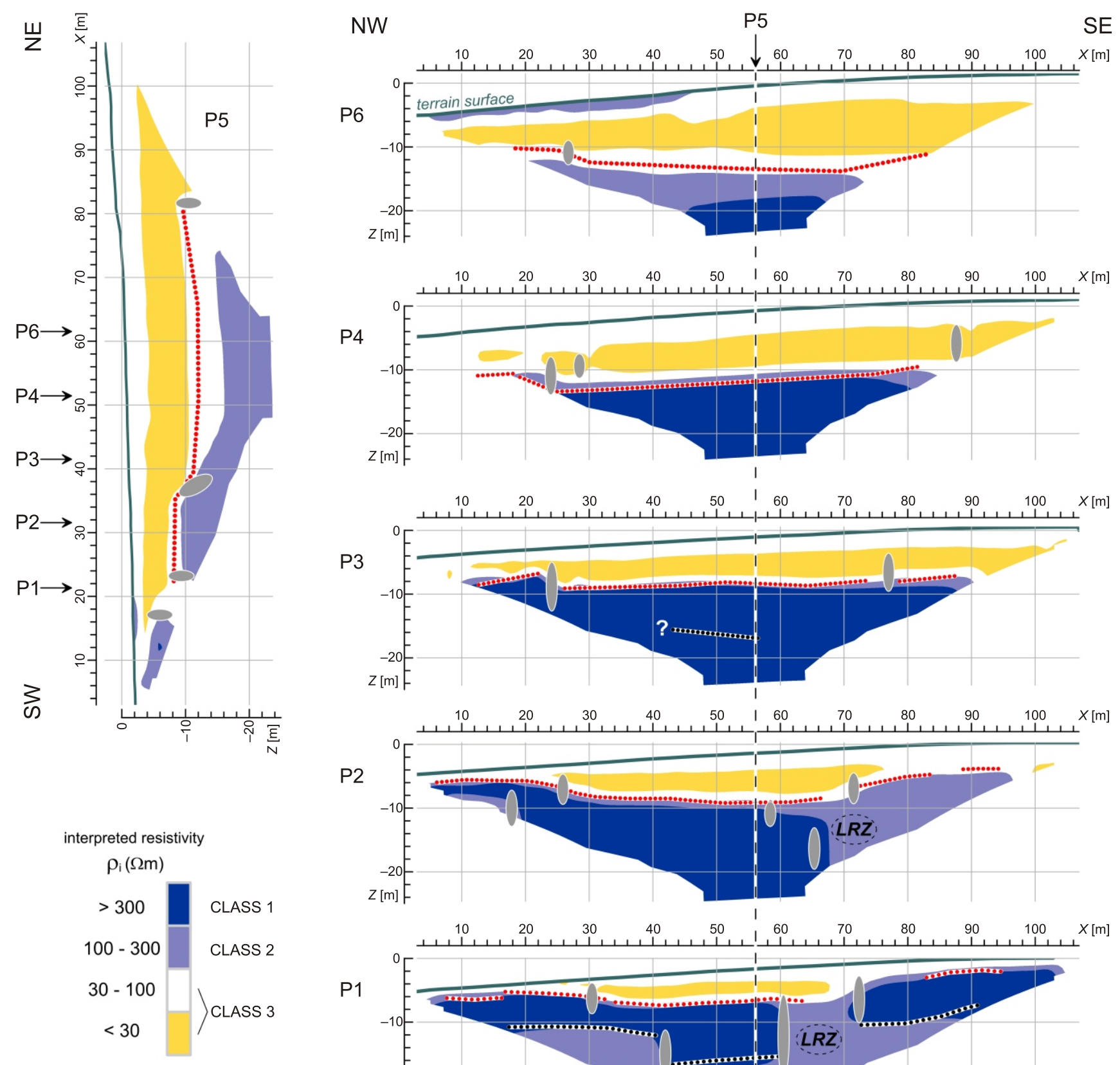

LRZ, low resistivity zone
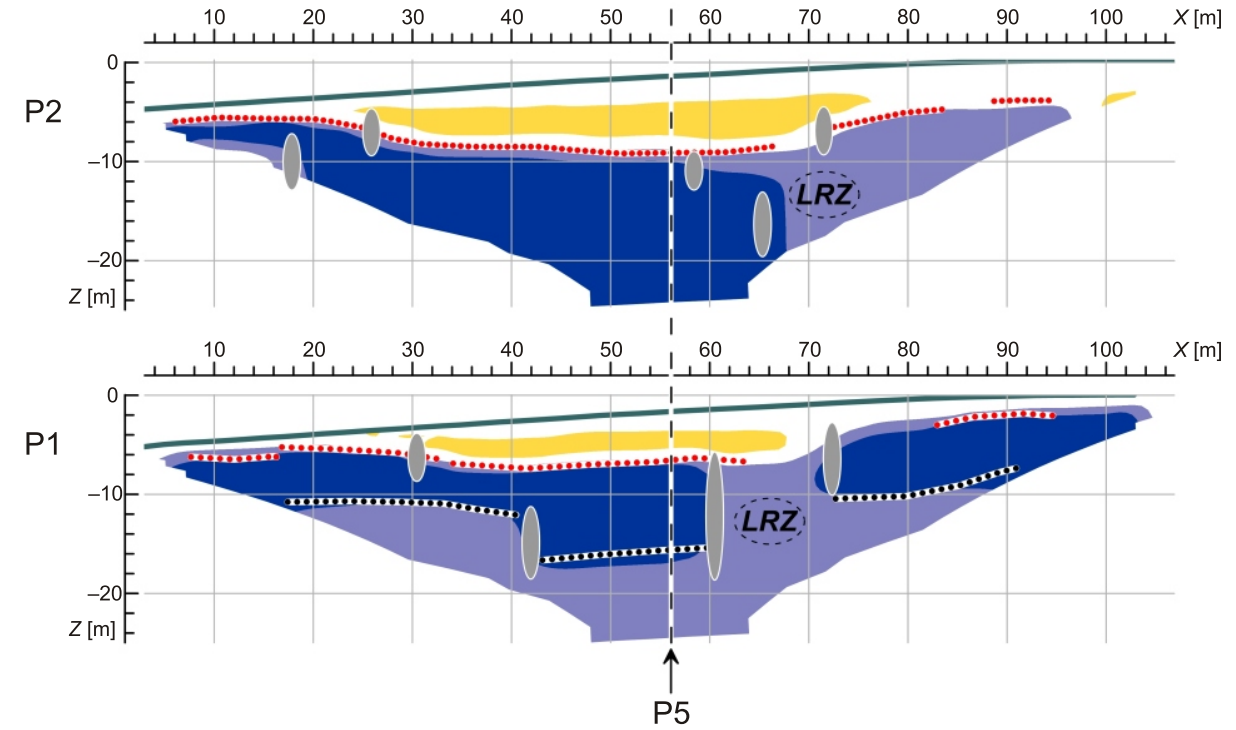

maximum POSITIVE values of the vertical gradient of the interpreted resistivity (change from the lower to the higher resistivity)

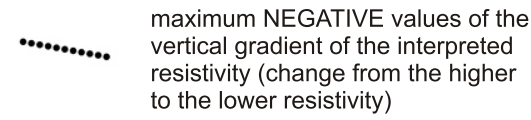

zones of the relatively strong horizontal gradient of the interpreted resistivity

Fig. 8. ERT field data inversion results with three adopted resistivity classes along with contours representing calculated maximum positive and negative values of the vertical and horizontal gradients based on the interpreted resistivities for ERT survey lines P1-P6

The classifications based on the resistivity classes should be regarded as an attempt to simplify the lithological identification based on the resistivity values 

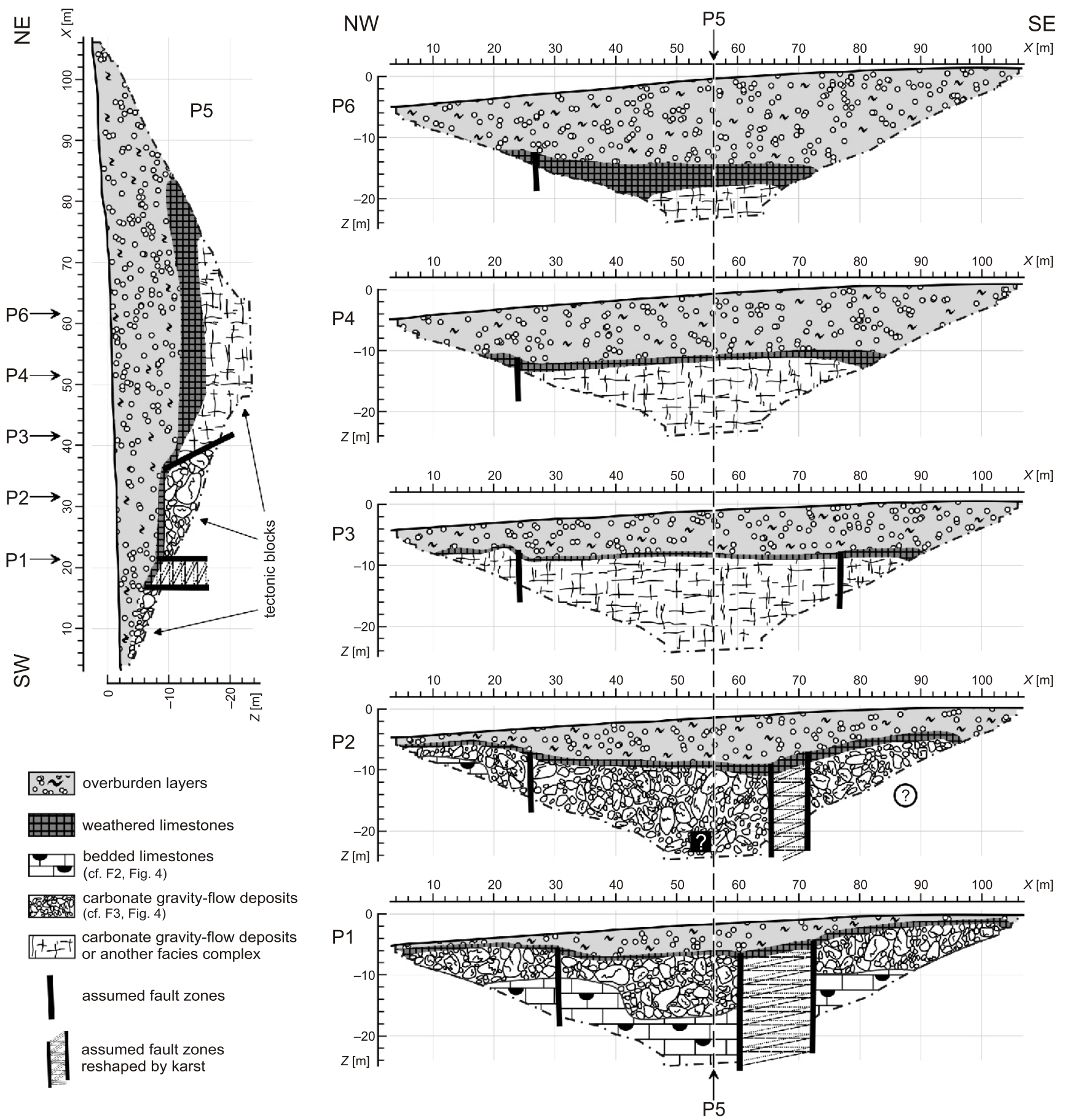

Fig. 9. Geological interpretation of the ERT survey lines (P1-P6) obtained by integration of all the research data

deposits apparent in the quarry wall (cf. F3, Fig. 4). The line of the maximum negative values of the vertical gradient, outlined on the P1 section (black dotted line, Fig. 8), emphasises the course of the lower boundary of these deposits. Unfortunately, the same surface is not apparent within the next P2 section, with the result that this boundary is unclear. Curiously, it reappears in the further cross-section P3 (white question mark, P3, Fig. 8). It should be noted that the position of this line, in the P3 section, cannot be treated with high confidence, because in this part of the interpreted section we are dealing with a homogeneous zone with a relatively high values of interpreted resistivity. This ambiguity may be due, e.g. from the nature of the inversion process (cf. Loke and Barker, 1996).
Assigning a particular facies type to the deposits of the first resistivity class that are visible in other cross-sections P3-P4-P6 (Fig. 8) seems to be difficult due to the presence of considerably higher values of resistivity in relation to the initial profiles P1-P2 (Fig. 7). These deposits may be interpreted as a continuation of the carbonate gravity-flow deposits, or as a different facies that represents e.g. massive limestones (cf. Fig. 9). Ambiguity in the facies interpretation (based on the resistivity distribution) may be connected with the fact that the measurements were performed at two different stages and therefore the weather conditions (governing humidity and water distribution in overburden deposits) may have affected the measurement results (e.g., Clément et al., 2009). 
The second resistivity class, which represents resistivity in the range of 100-300 $\Omega \mathrm{m}$ (cf. Fig. 8), can be interpreted in two ways. On the one hand, the zone that occurs immediately above the high resistivity sediments of the first class can be combined with a layer of weathered limestone (Fig. 9) except for the surface layer that is highlighted in section P6 (at 6-47 m), which in this case is one of the overburden layer (e.g., sandy soil). The line of the maximum positive values of the vertical gradient (red dotted line, Fig. 8), emphasises the top surface of the weathered zone of the Upper Jurassic limestones (Fig. 9). This zone occurs in the shallowest parts of the extreme SE and NW ends of the P1, P2 cross-sections as well as at the NW end of the P3 section (Figs. 9 and 10A). Within the central parts of the first three cross-sections, these deposits are at a depth $>9 \mathrm{~m}$, thus consistent with an eroded trough (cf. zone D; Fig. 10A).

The same resistivity zone (100-300 $\Omega \mathrm{m})$ that occurs immediately below the high resistivity sediments well up on P1 section, suggests the occurrence of a different limestone facies type. In this case, this zone may be associated with the bedded limestones (Fig. 9) that are present directly below the gravity-flow deposits (cf. F2, Fig. 4). Presumably this limestone type also appears in the next P2 cross-section where it is limited to the NW margin of the section (Fig. 9).

An interesting case of the second resistivity class occurs within the SE part of the P2 cross-section (at 72-96 m; Fig. 8). This particular part of the cross-section can be presumably assigned to the carbonate gravity-flow deposits together with zone of the weathered limestones (question mark in circle, Fig. 9). Moreover, the second resistivity class marked on the perpendicular section P5 (Fig. 8) can be equated with the rock that represents the facies variety described in the first resistivity class along with the zone of weathered limestones (Fig. 9). The difference in the resistivity distribution between parallel and perpendicular survey lines (e.g., P1 and P5) can be associated with a different electric current distribution within a complex geological structure.

Other deposits that have a resistivity of $<100 \Omega m$ represent the third resistivity class (cf. Fig. 8) and can be identified with

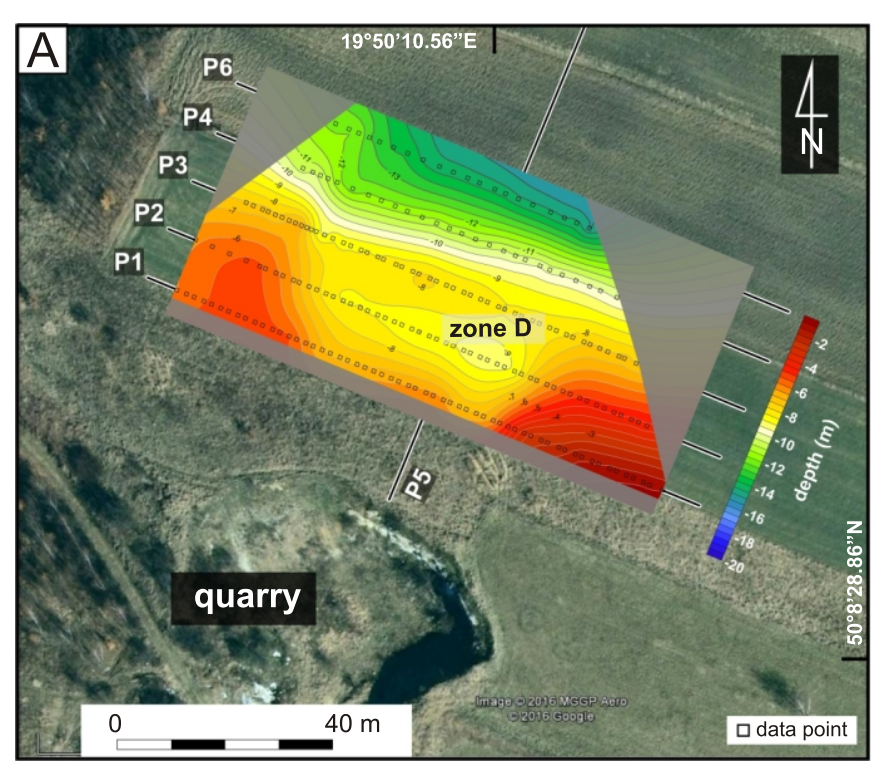

the post-Upper Jurassic deposits that form the overburden (Fig. 9).

Tectonic interpretation. The geophysical interpretation has also permitted us to identify tectonic phenomena, especially zones likely to represent series of faults or, more precisely fault zones, in the research area. These structures may cause the characteristic contour distribution, representing the value of the interpreted resistivity, which can be examined and investigated by numerical modelling (cf. Nguyen et al., 2005). The course of the faults was suggested based on the sections that had been compiled with the calculated values of the vertical as well as the horizontal gradients of the interpreted resistivity (Fig. 8). The presence of four fault zones in the study area is postulated (Fig. 9).

In the cross-section P1 over the distance of the $\sim 60-72 \mathrm{~m}$, a distinct break in the continuity of the maximum positive and negative values of the vertical gradient of the interpreted resistivity as well as in the strata attributable to the first and second resistivity class by a zone that reveals a lower resistivity value is evident (LRZ; Fig. 8). This situation is better reflected on the map that shows the top surface of the strata of the first resistivity class (Fig. 10B) with a resistivity of $>300 \Omega \mathrm{m}$. It is apparent that these rocks do not occur in certain parts of the maps, as is particularly visible in sections P1 and P2 (zone A, Fig. 10B). The lateral limitations of this zone match perfectly to the mutually parallel horizontal gradients of the interpreted resistivity positioned within cross-section P1 (at 60 and $72 \mathrm{~m}$ ) and P2 cross-section (at 66 and $72 \mathrm{~m}$; Fig. 8). The same zone on the further P3 section is less visible and is presumably limited only to the SE marginal part of the section. In our opinion, this zone, with an alleged NE-SW course, may be interpreted as fault fissure enlarged by karst processes (Fig. 9). Another fault which was probably reshaped by karstification is apparent at the SE end of cross-section P5 (Fig. 9) in the close proximity to cross-section $\mathrm{P} 1$. The lateral extent of this zone, which extends in a presumably WNW-ESE direction, is marked by the occurrence of two parallel zones of horizontal gradients $(X=\sim 16$ and 22 m; Fig. 8).

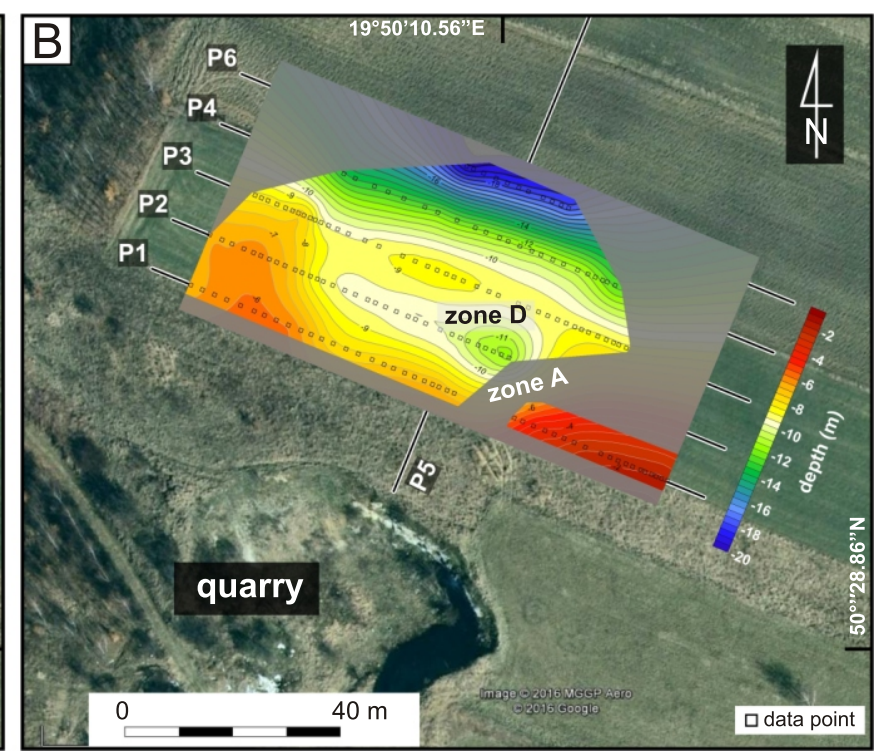

Fig. 10. Contour maps of Upper Jurassic limestone top surfaces (without tectonic phenomena)

A - top surfaces of the sediments assigned to the second resistivity class (cf. Fig. 8), which have been identified as zones of weathered limestone (cf. Fig. 9); B - top surfaces of the strata assigned to the first resistivity class (cf. Fig. 8), which have been identified as carbonate gravity-flow deposits and/or another facies type (cf. Fig. 9); source of orthophotomap( Google Earth web site) 


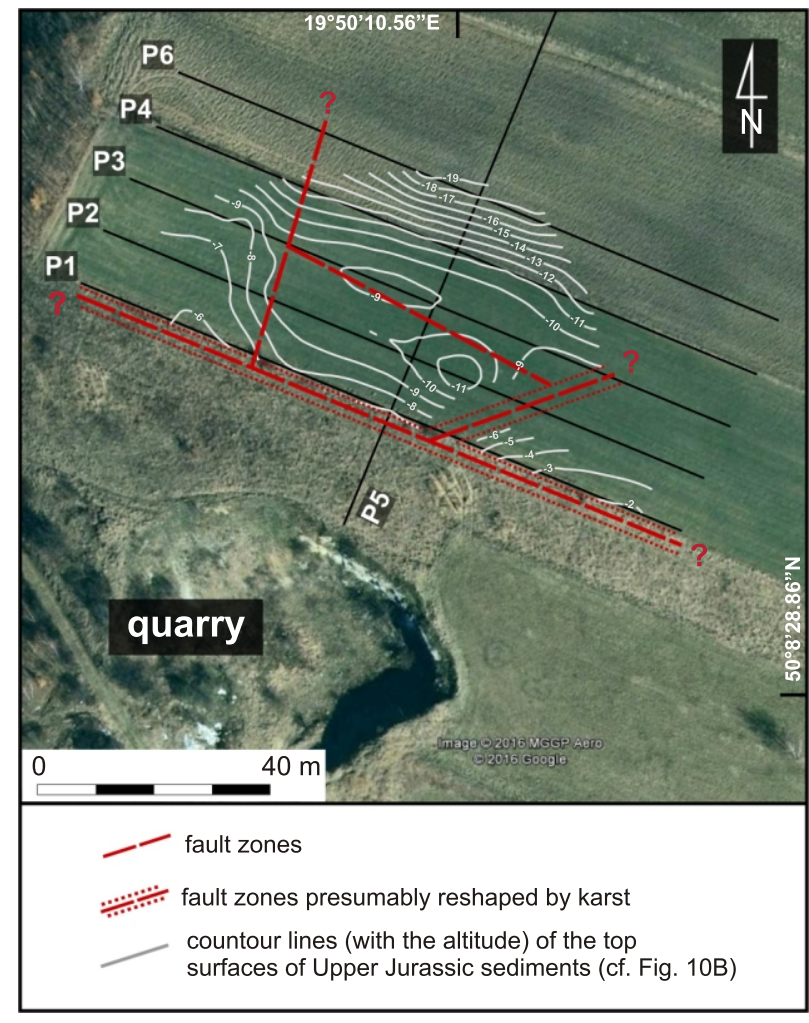

Fig. 11. Sketch map with the positions of the faults identified in the research area

Source of orthophotomap (Google Earth web site)

A distinct break in the continuity of the maximum positive values of the vertical gradient within the NW part of the P3 cross-section (between 22 and 26 m; Fig. 8) indicates another fault zone. The presumed NNE-SSW course of this fault has been defined on the basis of the horizontal gradients apparent on the subsequent P1-P2-P4 and P6 cross-sections. The last hypothetical fault, of alleged WNW-ESE course, is positioned in the zone between the P2 and P3 cross-sections. The faults emphasise the complex geological structure with small, distinctly tilted (toward the NE) fault blocks, clearly visible on the perpendicular P5 cross-section (Fig. 9).

Figure 11 depicts the schematic course of the interpreted fault zones based on the geological interpretation derived from Figure 9. All established faults represent a series of secondary faults, which are more or less perpendicular to the main faults which frame the structure of the Krzeszowice Graben (cf. Fig. 1).

REMARKS ON THE DEVELOPMENT OF THE UPPER JURASSIC LIMESTONES IN TOMASZOWICE QUARRY

According to Ziółkowski (2007b), the Upper Jurassic pelitic limestones (F1, Fig. 4) exposed in the lowermost part of the Tomaszowice Quarry represent a presumably similar sedimentary environment and time interval (?Middle Oxfordian) to the Upper Jurassic limestones described from the area of Korzkiew ( 7 km north-east of the studied outcrop; Ziółkowski, 2005).

The bedded limestones from the middle part of the Tomaszowice Quarry (F2, Fig. 4), were deposited in Late Jurassic shallow-water and open-marine epicontinental conditions (e.g., Leinfelder et al., 1996; Matyszkiewicz, 1997; Krajewski et al., 2016) and represent the Tubiphytes-Terebella association widely described from the literature (Leinfelder et al., 1996).
The Upper Jurassic deposits from the uppermost part of the quarry (F3, Fig. 4) display characteristics associated with carbonate gravity-flow deposits, such as debris flow deposits (cf. Flügel, 2004), in line with the observation of Ziółkowski (2007b). Based on the sedimentological study it cannot be excluded that these Upper Jurassic debris flow deposits might have formed by aggradational growth of several stacked individual debris flow surges (see e.g., Major, 1997; Sohn et al.,1999; Sohn, 2000; Tripsanas et al., 2003). However, the ERT methods did not discriminate details within the debris flow sedimentary body. Post-depositional processes such as dewatering, compaction and/or amalgamation may have led to the welding of single surges, which are not stratigraphically distinguishable, into the one unit that can be observed right now in the quarry (cf. Major, 1997; Sohn, 2000). The high proportions of limestone clasts with relative low matrix content, that according to Flügel (2004) is noncohesive in a carbonate debris flow, suggest that this debris must have been weak during deposition (cf. e.g., Surlyk, 1984). Such a composition results in presumably stiff plastic flow properties in which internal friction and clast shearing are responsible for a decelerating flow speed (Henrich, 2016). Such material within the flow structure could not be transported for long distances from the source area due to the lack of buoyancy (e.g., Drzewiecki and Simó, 2002).

The lower boundary of the debris flow deposits (revealing their typical erosive nature) may be identified with a basal shear surface where the downslope oriented shear stress exceeds the shear strength of a sediment (vide Frey-Martinez, 2010). However, such surfaces may result in the deposition of debris flow deposits that have high internal shear near the base of the flow (Middleton, 1970).

The deposition of the debris flows analysed probably took place in the zones that represent the proximal parts of the slopes of carbonate buildups or their complexes and supposedly corresponds to the Upper Jurassic Oxfordian-Kimmeridgian stage boundary (Fig. 3; cf. Matyszkiewicz, 1996; 1997). With respect to the gravity-flow deposits at Tomaszowice, similar deposits (in close proximity to the site examined) of comparable age have been comprehensively identified at Ujazd and Giebultów. In agreement with observations provided by Ziółkowski (2007a), the Upper Jurassic deposits represent the Bimmamatum-Platynota zone at Ujazd and the Lowermost Kimmeridgian sublevel Polygyratus-Desmoides of the Platynota zone at Giebultów.

The direction of the erosional channel (Fig. 4B) documents the presumably $\mathrm{N}-\mathrm{S}$ or NE-SW sediment transport direction towards the present-day centre of the Krzeszowice Graben. Furthermore, the observed channel orientation is almost parallel to that of the nearby faults (Fig. 9), which corresponds to the northern boundary of the Krzeszowice Graben (Fig. 1). It is widely accepted in the literature (e.g., Matyszkiewicz, 1996; Ziółkowski, 2007a) that at least a portion of the faults which bound the structure of the Krzeszowice Graben already existed in Late Jurassic or even earlier times and were subject to multiple Alpine reactivation (Matyszkiewicz et al., 2007; Nawrocki et al., 2008; Habryn et al., 2014; Matyja and Ziółkowski, 2014). The same situation appears to hold for the faults (Fig. 8) which were identified in the research area.

The presence of Upper Jurassic debris flow deposits at Tomaszowice records Late Jurassic synsedimentary fault tectonics, which was a repercussion of the transregional factors that were responsible for opening both the North Atlantic and Tethys Oceans (Ziegler, 1990; Allenbach, 2002). Fault tectonic activity plays a major role in the initiation of gravity flows, and also affects their character by influencing factors such as sediment production and slope morphology (cf. Pochat and Van Den Driessche, 2007; Quiquerez et al., 2013). In the research 
area, tectonic activity was accompanied by the rejuvenation of older Paleozoic structures in the homocline basement, in particular the Kraków-Lubliniec Fault Zone (e.g., BrochwiczLewiński et al., 1984; Żaba, 1999; Matyszkiewicz et al., 2006, 2007, 2012, 2015a, b).

\section{CONCLUSIONS}

1. Electrical resistivity tomography together with sedimentological study was used to investigate the Upper Jurassic limestones at the Tomaszowice Quarry, located within the northern margin of the Krzeszowice Graben (southern Poland).

2. The correlation between the exposed Upper Jurassic limestones and the ERT images obtained (on which resistivity classes have been established) has allowed their interpretation in the subsurface as constraint of their lateral distributions. The first resistivity class $(>300 \Omega \mathrm{m})$ was identified for the most part as debris flow deposits, perhaps with massive limestones. A second resistivity class $(100-300 \Omega m)$ was correlated with bedded limestones, zones of weathered limestones and rocks attributable to the first resistivity class. Both of these classes refer only to the Upper Jurassic limestones, while a third resistivity class $(<100 \Omega \mathrm{m})$ represents overburden layers that are younger than Upper Jurassic. On general grounds, the obtained re- sults provide and supplied information to the its geological interpretations.

3. The ERT results (analyses of the vertical and horizontal gradients) showed the usefulness of this technique for the delineating zones that may be interpreted as fault zones. The data presented suggest occurrence of four fault zones, of which two are enlarged, presumably by karst processes.

4. The presence of gravity-flow sediments such as debris flow deposits in the marginal zones of the Krzeszowice Graben reflects Late Jurassic activity of the faults that formed the graben. This phenomenon was connected with the reactivation of the preexisting Kraków-Lubliniec Fault Zone.

Acknowledgements. We are grateful to Prof. J. Matyszkiewicz (AGH University of Science and Technology, Kraków, Poland) for his scientific support and constructive comments, which significantly helped to improve the manuscript. We are indebted to Mrs. M. Simons for corrections to the manuscript, Prof. B. Olszewska for kindly helping with microfauna determination as well as Mr. S. Szczurek for helping with the fieldwork. We would like to thank the two reviewers Dr. K. Wójcik (Polish Geological Institute - National Research Institute, Warszawa, Poland) and Dr. M. Gradziński (Jagiellonian University, Kraków, Poland) for their constructive comments that considerably improved this paper. The research was financially supported by the AGH University of Science and Technology grant No.15.11.140.637.

\section{REFERENCES}

Allenbach, R.P., 2002. The ups and downs of "Tectonic Quiescence" - recognizing differential subsidence in the epicontinental sea of the Oxfordian in the Swiss Jura Mountains. Sedimentary Geology, 150: 323-342.

Bania, G., 2011. Wpływ topografii terenu na wyniki badań metoda tomografii elektrooporowej - wybrane zagadnienia (in Polish). Unpubl. M.Sc. thesis, AGH University of Science and Technology, Kraków, Poland.

Barski, M., Mieszkowski, R., 2014. Upper Jurassic large-scale debris flow deposits in interbiohermal basins of the sponge megafacies in Poland - new insights. Neues Jahrbuch für Geologie und Paläontologie Abhandlungen, 272: 47-59.

Bice, D.M., Stewart, K.G., 1990. The formation and drowning of isolated carbonate seamounts: tectonic and ecological controls in the northern Apennines. IAS Special Publication, 9: 145-168.

Bogacz, K., 1964. Budowa geologiczna południowej części Wyżyny Krakowskiej w świetle badań z lat 1953-1963 (in Polish). Sprawozdanie z Posiedzeń Komisji PAN: 256-258.

Bogacz, K., 1967. The geological structure of the northern border of the Krzeszowice Graben (in Polish with English summary). Prace Geologiczne, 41: 1-89.

Brochwicz-Lewiński, W., Gasiewicz, A., Strzelecki, R. Suffczynski, S., Szatkowski, K., Tarkowski, R., Żbik, M., 1984. Geochemical anomaly at the Middle-Upper Jurassic boundary in southern Poland (in Polish with English summary). Przegląd Geologiczny, 32: 647-650.

Bukowy, S., 1960. Submarine slides in the rocky limestones near Cracow (in Polish with English summary). Biuletyn Instytutu Geologicznego, 155: 153-168.

Buła, Z., Jachowicz, M., Żaba, J., 1997. Principal characteristics of the Upper Silesian Block and Małopolska Block border zone (southern Poland). Geological Magazine, 134: 669-677.

Buła, Z., Habryn, R., Krieger, W., Kurek, S., Maćkowiak, M., Woźniak, P., 2002. Atlas geologiczny paleozoiku bez permu w strefie kontaktu bloków górnośląskiego i małopolskiego, 1:200 000 (in Polish). PIG, Warszawa.

Burzewski, W., 1969. Les conditions structurales du Jurassique de la règion d'Olkusz et de Wolbrom comme bordières pour les gisements pètrolifères du Basssin de Nida (in Polish with French summary). Prace Geologiczne, 61: 3-91.

Clément, R., Descloitres, M., Günther, T., Ribolzi, O., Legchenko, A., 2009. Influence of shallow infiltration on time-lapse ERT: experience of advanced interpretation. Comptes Rendus Geoscience, 341: 886-898.

Ćwiklik, M., 2013. Characterization of near-surface sediments based on Electrical Resistivity Tomography measurements in the vicinity of the Wawel Hill (Krakow, Poland). Geology, Geophysics \& Environment, 39: 351-361.

Dahlin, T., Zhou, B., 2004. A numerical comparison of 2D resistivity imaging with 10 electrode arrays. Geophysical Prospecting, 52: 379-398.

Drzewiecki, P.A., Simó, J.A., 2002. Depositional processes, triggering mechanisms and sediment composition of carbonate gravity flow deposits: examples from the Late Cretaceous of the south-central Pyrenees, Spain. Sedimentary Geology, 146: 155-189.

Dunham, R.J., 1962. Classification of carbonate rocks according to depositional texture. AAPG Memoir, 1: 108-121.

Dżułyński, S., 1952. The origin of the Upper Jurassic limestone in the Cracow area (in Polish with English summary). Rocznik Polskiego Towarzystwa Geologicznego, 21: 125-180.

Dżułyński, S., 1953. Tektonika południowej części Wyżyny Krakowskiej (in Polish). Acta Geologica Polonica, 3: 325-440.

Embry III, A.F., Klovan, J.E., 1972. Absolute water depth limits of Late Devonian paleoecological zones. Geologische Rundschau, 61: 672-686. 
Flügel, E., 2004. Microfacies of Carbonate Rocks: Analysis, Interpretation and Application. Springer, Berlin, Heidelberg, New York.

Frey-Martínez, J., 2010. 3D seismic interpretation of mass transport deposits: implications for basin analysis and geohazard evaluation. In: Submarine Mass Movements and Their Consequences (eds. D.C. Mosher, R.C. Shipp, L. Moscardelli, J.D. Chaytor, C.D.P. Baxter, H.J. Lee and R. Urgeles): 553-568. Springer, Netherlands.

Gaillard, C., 1983. Les biohermes à spongiaires et leur environment dans l'Oxfordian du Jura meridional. Documents des Laboratoires de Géologie de la Faculté des Sciences de Lyon 90: 1-515.

Głazek, J., Wierzbowski, A., 1972. On the alleged Kimmeridgian transgression in the Cracow Upland. Acta Geologica Polonica, 22: $45-70$

Gradziński, R., 1972. Przewodnik geologiczny po okolicach Krakowa (in Polish). Wyd. Geol., Warszawa.

Gradziński, R., 2009. Geological map of Kraków region without Quaternary and terrestrial Tertiary deposits. Wydawnictwo Instytutu Nauk Geologicznych PAN, Kraków.

Gwinner, M.P., 1976. Origin of the Upper Jurassic Limestones of the Swabian Alb (Southwest Germany). Contributions to Sedimentology, 5: 1-76.

Habryn, R., Buła, Z., Nawrocki, J., 2014. The Kraków sector of the Kraków-Lubliniec tectonic zone in the light of data obtained from new boreholes of Trojanowice 2 and Cianowice 2 (in Polish with English summary). Biuletyn Państwowego Instytutu Geologicznego, 459: 47-60.

Henrich, R., 2016. Synsedimentary tectonics and mass wasting along the Alpine margin in Liassic time. In: Submarine Mass Movements and their Consequences (eds. G. Lamarche, J. Mountjoy, S. Bull, T. Hubble, S. Krastel, E. Lane, A. Micallef, L. Moscardelli, C. Mueller, I. Pecherand and S. Woelz): 449-459 Springer International Publishing.

Hirsch, M., Bentley, L.R., Dietrich, P., 2008. A comparison of electrical resistivity, ground penetrating radar and seismic refraction results at a river terrace site. Journal of Environmental \& Engineering Geophysics, 13: 325-333.

Hoffmann, M., Matyszkiewicz, J., 1989. Wykształcenie litologiczne i sedymentacja osadów jury w kamieniołomie Młynka (in Polish). In: Przewodnik LX Zjazdu Polskiego Towarzystwa Geologicznego, Państwowy Instytut Geologiczny (ed. J. Rutkowski): 78-82. Wydawnictwa AGH, Kraków.

Koszarski, A., 1995. Tradycja a nowoczesność w interpretacji warunków powstania wapieni górnej jury krakowskiej. Szczególna rola procesów redepozycji. Studium terenowe (in Polish). In: Tradycja a nowoczesność w interpretacjach sedymentologicznych (eds. M. Doktor, A. Głuszek, D. Gmur and T. Słomka): 9-22. Materiały Konferencyjne IV Krajowego Spotkania Sedymentologów, Kraków.

Kozłowska, M., Barski, M., Mieszkowski, R., Antoszewska, K. 2016. A new Triassic-Jurassic section in the southern part of the Holy Cross Mts. (Poland) implications for palaeogeography. Geological Quarterly, 60 (2): 365-484.

Krajewski, M., 2000. Lithology and morphology of Upper Jurassic carbonate buildups in the Będkowska Valley, Kraków region, Southern Poland. Annales Societatis Geologorum Poloniae,70: 51-136.

Krajewski, M., Olchowy, P., Felisiak, I., 2016. Late Jurassic facies architecture of the Złoczew Graben: implications for evolution of the tectonic-controlled northern Peri-Tethyan shelf (Upper Oxfordian-Lower Kimmeridgian, Poland). Facies, 62: 4.

Leinfelder R.R., Werner, W., Nose, M., Schmid, D.U., Krautter, M., Laterneser, R.R., Tacacs, M., Hartmann, D., 1996. Paleoecology, growth parameters and dynamics of coral, sponge and microbolite reefs from the Late Jurassic. Göttinger Arbeiten zur Geologie and Paläontologie, Sb 2: 227-248.

Loke, M.H., 2010. Rapid 2D Resistivity \& IP Inversion Using Least-Squares Method. Geotomo Software. Manual.

Loke, M.H., 2011. Tutorial: 2-D and 3-D Electrical Imaging Surveys. Geomoto Software. Malaysia.
Loke, M.H., Barker, R.D., 1996. Rapid least-squares inversion of apparent resistivity pseudosections by a quasi-Newton method. Geophysical Prospecting, 44: 131-152.

Loke, M.H., Ackworth, I., Dahlin, T., 2003. A comparison of smooth and blocky inversion methods in $2 \mathrm{D}$ electrical imaging surveys. Exploration Geophysics, 34: 182-187.

Major, J.J., 1997. Depositional processes in large-scale debris-flow experiments. The Journal of Geology, 105: 345-366.

Matyja, B.A., Ziółkowski, P., 2014. Upper Jurassic stratigraphy and facies differentiation - a case study of the Cianowice 2 and Trojanowice 2 boreholes (Olkusz Upland and Krzeszowice Graben borderland) (in Polish with English summary). Biuletyn Państwowego Instytutu Geologicznego, 459: 93-108.

Matyszkiewicz, J., 1989. Sedimentation and diagenesis of the Upper Oxfordian cyanobacterial-sponge limestones in Piekary near Kraków. Annales Societatis Geologorum Poloniae, 59: 201-232.

Matyszkiewicz, J., 1996. The significance of Saccocoma-calciturbidites for the analysis of the Polish epicontinental late Jurassic Basin: an example from the Southern Cracow-Wielun Upland (Poland). Facies, 34: 23-40.

Matyszkiewicz, J., 1997. Microfacies, sedimentation and some aspects of diagenesis of Upper Jurassic sediments from the elevated part of the Northern peri-Tethyan Shelf, a comparative study on the Lochen area (Schwabische Alb) and the Cracow area (Cracow-Wielun Upland, Poland). Berliner Geowissenschaftliche Abhandlungen, E21: 1-111.

Matyszkiewicz, J., 1999. Sea-bottom relief versus differential compaction in ancient platform carbonates: a critical reassessment of an example from Upper Jurassic of the Cracow-Wieluń Upland. Annales Societatis Geologorum Poloniae, 69: 63-79.

Matyszkiewicz, J., Krajewski, M., 1996. Lithology and sedimentation of Upper Jurassic massive limestones near Bolechowice, Kraków-Wieluń Upland, south Poland. Annales Societatis Geologorum Poloniae, 66: 201-232.

Matyszkiewicz, J., Olszewska, B., 2007. Osady podmorskich spływów grawitacyjnych pogranicza oksfordu i kimerydu w Ujeździe (in Polish). Tomy Jurajskie, 4: 109-117.

Matyszkiewicz, J., Krajewski, M., Żaba, J., 2006. Structural control on the distribution of Upper Jurassic carbonates buildups in the Kraków-Wieluń Upland (south Poland). Neues Jahrbuch für Geologie und Paläontologie Monatschefte, 3: 182-192.

Matyszkiewicz, J., Świąder, J., Żaba, J., 2007. Przejawy późnojurajskiej tektoniki synsedymentacyjnej w rejonie Kamienia (in Polish). Tomy Jurajskie, 4: 63-70.

Matyszkiewicz, J., Kochman, A., Duś, A., 2012. Influence of local sedimentary conditions on development of microbialites in the Oxfordian carbonate buildups from the southern part of the Kraków-Częstochowa Upland (south Poland). Sedimentary Geology, 263-264: 109-132.

Matyszkiewicz, J., Kochman, A., Rzepa, G., Gołębiowska, B., Krajewski, M., Gaidzik, K., Żaba, J., 2015a. Epigenetic silicification of the Upper Oxfordian limestones in the Sokole Hills (Kraków-Częstochowa Upland): relationship to facies development and tectonics. Acta Geologica Polonica, 65: 192-214.

Matyszkiewicz, J., Felisiak, I., Hoffmann, M., Kochman, A., Kołodziej, B., Krajewski, M., Olchowy, P., $2015 \mathrm{~b}$. Transgressive Callovian succession and Oxfordian microbial-sponge carbonate buildups in the Kraków Upland. In: Guidebook for Field Trips Accompanying 31st IAS Meeting of Sedimentology Held in Kraków on 22nd-25th of June (ed. G. Haczewski): 51-74. Polskie Towarzystwo Geologiczne.

Matyszkiewicz, J., Krajewski, M., Kochman, A., Kozłowski, A., Duliński, M., 2016. Oxfordian neptunian dykes with brachiopods from the southern part of the Kraków-Częstochowa Upland (southern Poland) and their links to hydrothermal vents. Facies, 62: 1-28.

Middleton, G.V., 1970. Experimental studies related to problems of flysch sedimentation. Geological Association of Canada Special Paper, 7: 253-272. 
Morawska, A., 1997. The Lubliniec fracture zone: boundary of the Upper Silesia and Małopolska massifs, southern Poland. Annales Societatis Geologorum Poloniae, 67: 429-437.

Mościcki, W.J., Antoniuk, J., 1999. Metodyka obrazowania elektrooporowego (resistivity imaging) (in Polish). Przykłady badań dla celów geologiczno-inżynierskich, Geofizyka w Geologii, Górnictwie i Ochronie Środowiska. V Konferencja Naukowo-Techniczna, Kraków: 315-325.

Mościcki, W.J., Bania, G., Ćwiklik, M., Borecka, A., 2014. DC resistivity studies of shallow geology in the vicinity of Vistula River flood bank in Czernichów village (near Kraków in Poland). Studia Geotechnica et Mechanica, 36: 63-70.

Narkiewicz, M., Petecki, Z., 2017. Basement structure of the Paleozoic Platform in Poland. Geological Quarterly, 61 (2): 502-520.

Nawrocki, J., Fanning, M., Lewandowska, A., Polechońska, O., Werner, T., 2008. Palaeomagnetism and the age of the Cracow volcanic rocks (S Poland). Geophysical Journal International, 174: 475-488.

Nguyen, F., Garambois, S., Jongmans, D., Pirard, E., Loke, M.H., 2005. Image processing of $2 \mathrm{D}$ resistivity data for imaging faults. Journal of Applied Geophysics, 57: 260-277.

Olóriz, F., Reolid, M., Rodríguez-Tovar, F.J., 2003. A Late Jurassic carbonate ramp colonized by sponges and benthic microbial communities (External Prebetic, Southern Spain). Palaios, 18: 528-545.

Pellicer, X.M., Gibson, P., 2011. Electrical resistivity and Ground Penetrating Radar for the characterisation of the internal architecture of Quaternary sediments in the Midlands of Ireland. Journal of Applied Geophysics, 75: 638-647.

Pochat, S., Van Den Driessche, J., 2007. Impact of synsedimentary metre-scale normal fault scarps on sediment gravity flow dynamics: an example from the Grès d'Annot Formation, SE France. Sedimentary Geology, 202: 796-820.

Quiquerez, A., Sarih, S., Allemand, P., Garcia, J.P., 2013. Fault rate controls on carbonate gravity-flow deposits of the Liassic of Central High Atlas (Morocco). Marine and Petroleum Geology, 43: 349-369.

Reolid, M., Gaillard, C., Olóriz, F., Rodríguez-Tovar, F.J., 2005. Microbial encrustations from the Middle Oxfordian-earliest Kimmeridgian lithofacies in the Prebetic Zone (Betic Cordillera, southern Spain): characterization, distribution and controlling factors. Facies, 50: 529-543.

Senowbari-Daryan, B., Bucur, I.I., Schlagintweit, F., Săsăran, E., Matyszkiewicz, J., 2008. Crescentiella, a new name for "Tubiphytes" morronensis CRESCENTI, 1969: an enigmatic Ju-
rassic-Cretaceous microfossil. Geologia Croatica, 61: 185-214.

Šilhán, K., Pánek, T., 2010. Fossil and recent debris flows in medium-high mountains (Moravskoslezské Beskydy Mts., Czech Republic). Geomorphology, 124: 238-249.

Sohn, Y.K., 2000. Depositional processes of submarine debris flows in the Miocene fan deltas, Pohang Basin, SE Korea with special reference to flow transformation. Journal of Sedimentary Research, 70: 491-503.

Sohn, Y.K., Rhee, C.W., Kim, B.C., 1999. Debris flow and hyperconcentrated flood-flow deposits in an alluvial fan, northwestern part of the Cretaceous Yongdong basin, central Korea. The Journal of Geology, 107: 111-132.

Surlyk, F., 1984. Fan-delta to submarine fan conglomerates of the Volgian-Valanginian Wollastan Forland group, east Greenland. Canadian Society of Petroleum Geologists Memoir, 10: 359-382.

Szalai, S., Szarka, L., 2000. An approximate analytical approach to compute geoelectric dipole-dipole responses due to a small buried cube. Geophysical Prospecting, 48: 871-885.

Tripsanas, E.K., Bryant, W.R., Prior, D.B., 2003. Structural characteristics of cohesive gravity-flow deposits, and a sedimentological approach on their flow mechanisms. In: Submarine Mass Movements and Their Consequences (eds. J. Locat, J. Mienert and L. Boisvert): 129-136. Springer, Netherlands.

Ziegler, P.A., 1990. Geological Atlas of Western and Central Europe. Shell Internationale Petroleum Maatschapij, The Hauge.

Ziółkowski, P., 2005. Deformacje skamieniałości śladowych a proces kompakcji w wapieniach mikrytowych górnej jury okolic Korzkwi (Wyżyna Krakowska) (in Polish). Tomy Jurajskie, 3: $55-61$.

Ziółkowski, P., 2007a. Stratygrafia i zróżnicowanie facjalne górnej jury wschodniej części Wyżyny Krakowskiej (in Polish). Tomy Jurajskie, 4: 25-38.

Ziółkowski, P., 2007b. Osady basenów międzybiohermalnych sąsiadujących z południową krawędzią zespołu biohermalnego Ojcowa (in Polish). Tomy Jurajskie, 4: 119-122.

Żaba, J., 1995. Strike-slip faults at the edge zone of Upper Silesia and Małopolska blocks (southern Poland) (in Polish with English summary). Przegląd Geologiczny, 43: 838-842.

Żaba, J., 1999. The structural evolution of Lower Paleozoic succession in the Upper Silesia Block and Małopolska Block border zone, southern Poland (in Polish with English summary). Prace Państwowego Instytutu Geologicznego, 166: 1-162. 